\title{
Pemanfaatan Aplikasi M-Commerce untuk Memasarkan Produk Hasil Pengolahan Limbah Tempurung Kelapa
}

\author{
Yuni Nustini $^{1 *}$, Allwar Allwar ${ }^{2}$ \\ 1Program Studi Akuntansi Fakultas Bisnis dan Ekonomika Universitas Islam Indonesia, Yogyakarta, Indonesia \\ ${ }^{2}$ Program Studi Kimia Fakultas Matematika dan IImu Pengetahuan Alam Universitas Islam Indonesia, \\ Yogyakarta, Indonesia \\ ${ }^{*}$ Corresponding author: 903120102@uii.ac.id
}

\section{Abstrak}

Program pengabdian kepada masyarakat ini bertujuan untuk menaikkan pendapatan masyarakat melalui penjualan produk arang aktif di marketplace. Desa-desa di Kecamatan Bruno, Purworejo menghasilkan limbah tempurung kelapa dalam jumlah yang banyak. Dengan adanya unit produksi arang aktif dari limbah tempurung kelapa, maka akan menciptakan lapangan pekerjaan. Program-program yang dilaksanakan adalah berupa pembimbingan dan praktik pembuatan arang aktif, penyediaan mesin pemroses tempurung kelapa menjadi arang aktif, dan peralatan pembantu produksi. Dilanjutkan dengan pembimbingan hands-on pembuatan "Toko" di marketplace Shopee. Output program ini adalah keberhasilan produksi arang aktif sampai dengan pengemasannya sehingga siap untuk dijual, dan dimilikinya "Toko" di Shopee. Di akhir program, produk sudah dipasarkan melalui mobile-commerce marketplace Shopee.

Kata kunci: tempurung kelapa; arang aktif; marketplace

\section{Abstract}

The objective of this community service program was to increase the income for the people of Bruno District, Purworejo through the selling of activated charcoal in a marketplace. Villages in the Bruno District produce large quantities of waste coconut shell. The activated charcoal was manufactured from waste coconut shells. Meanwhile, this production unit will create jobs and increase employability. Some programs that had been executed include tutorial and training of producing activated charcoal, sponsoring (providing) machineries as well as equipment to process coconut shells to become activated charcoal. Next, the program was a hands-on learning on how to develop "a Store" at the Shopee marketplace. Output of the program was activated charcoal that packed in a marketable branded plastic bag and ready for sale. Finally, the output was engage in a "shop" at a mobile-commerce Shopee, and at the end of the program, the product had been broadcasted and sold through the Shopee marketplace.

Keywords: coconut shell; activated charcoal; marketplace

Cite this article: Nustini, Y., \& Allwar, A. (2021). Pemanfaatan Aplikasi M-Commerce untuk Memasarkan Produk Hasil Pengolahan Limbah Tempurung Kelapa. Rahmatan Lil'alamin Journal of Community Services, 1 (1).

\section{Pendahuluan}

Indonesia merupakan negara sebagai penghasil buah kelapa terbesar di dunia. Kita akan menjumpai pohon kelapa di seantero kepulauan di Indonesia. Maka tidaklah mengherankan apabila banyak desa di Indonesia memiliki hasil dari pohon kelapa yang melimpah ruah. Sejak dahulu kala oleh nenek moyang kita, semua bagian dari Pohon Kelapa telah 
dimanfaatkan. Mulai dari daun di puncak pohonnya sampai dengan akarnya di dalam bumi, semua dapat termanfaatkan. Kita semua sudah pasti mengetahui bahwa daging buah kelapa dapat diolah menjadi berbagai jenis makanan yang lezat. Sementara itu tempurung kelapa yang membungkus daging kelapa dapat dimanfaatkan menjadi berbagai jenis produk kerajinan, daun kelapa dipergunakan untuk atap, tikar, atau anyaman lainnya, sedangkan batang pohonnya yang tinggi dan besar ternyata sangat kuat dan tahan segala cuaca sehingga baik untuk dimanfaatkan sebagai material pembuat bangunan. Akhirnya, sisa-sisa dari semua bagian pohon kelapa tadi masih dapat dipergunakan sebagai media pembakaran, seperti halnya kayu bakar.

Melimpahnya hasil buah kelapa, akan diikuti dengan adanya limbah buah kelapa. Di desa-desa di Kecamatan Bruno, Purworejo banyak ditanam pohon kelapa. Limbah buah kelapa dapat dijumpai di banyak desa di Kecamatan Bruno. Karena jumlah dan volumenya banyak, maka limbah ini sangat potensial untuk dijadikan sebagai sumber pendapatan masyarakat sehingga dapat menaikkan tingkat perekonomian penduduk Bruno. Limbah tempurung kelapa dapat diproses atau didaur ulang menjadi berbagai macam produk yang bernilai ekonomis tinggi.

Di Kecamatan Bruno, tempurung kelapa dan sabut kelapa tidak dimanfaatkan dengan baik. Selama ini sabut dan tempurung kelapa hanya dimanfaatkan sebagai bahan bakar untuk keperluan memasak sehari-hari di rumah tangga, artinya belum dioptimalkan manfaat ekonomisnya. Beberapa program pelatihan dari pemerintah maupun organisasi masyarakat sudah pernah dilaksanakan dengan tujuan untuk meningkatkan nilai ekonomis dari tempurung kelapa. Tempurung yang selama ini menjadi limbah dapat diproses lebih lanjut menjadi suvenir pariwisata, menjadi peralatan rumah tangga, tas, dan beberapa jenis produk suvenir lainya. Amat disayangkan, sampai saat ini program-program pelatihan tersebut hasilnya masih jauh dari yang diharapkan. Ditengarai permasalahan utamanya berasal dari tidak mudahnya produk barang suvenir tersebut dipasarkan.

Prioritas program pengabdian pada masyarakat ini menginisiasi pembuatan "Toko" di sebuah marketplace sebagai media untuk memasarkan produk arang aktif hasil pengolahan limbah tempurung kelapa di Kecamatan Bruno Purworejo. Sebelum membuka toko daring, maka akan diawali dengan program inovasi pemanfaatan limbah tempurung kelapa untuk diproses menjadi arang aktif atau karbon aktif sebagai bahan penyerap limbah industri dan rumah tangga. Target jangka panjang konsumen produk ini bukanlah orang perorangan, akan tetapi industri karena arang aktif banyak dipergunakan oleh industri sebagai penyerap bau ataupun penyaring air kotor dan limbah di udara. Dengan target konsumen industri, diharapkan penjualan akan dapat dilakukan dalam volume yang besar selanjutnya berkontribusi signifikan menaikkan perekonomian masyarakat. Meskipun demikian, pada tahap awal ketika produksi belum mencukupi untuk skala industri maka tentu saja akan dipasarkan kepada masyarakat umum orangperorangan atau industri kecil (UKM). Pembukaan unit pengolahan limbah tempurung menjadi arang aktif akan menciptakan lapangan pekerjaan baru bagi masyarakat di desa-desa di Kecamatan Bruno. 
Arang aktif dapat dimanfaatkan sebagai pembersih udara pada ruangan yang lembab dan berbau, seperti pada mobil, lemari, gudang, dan kamar berpendingan. Selain itu arang aktif juga dipergunakan sebagai penyerap udara/gas yang berbau, penyerap bau pada air sumur, serta menjaga peralatan dari proses korosi dan karat. Kesimpulannya, arang aktif banyak dipergunakan sebagai pengolah limbah cair, penyerap material pengotor yang terdapat dalam air dan limbah di udara. Limbah cair dari buangan rumah tangga dan industri berpotensi untuk merusak lingkungan bahkan mematikan makhluk hidup sehingga merusak rantai kehidupan.

Mobile commerce (m-commerce) sebuah pengembangan dari teknologi electronic commerce saat ini sudah sangat dikenal oleh segala lapisan masyarakat. Mobile commerce merupakan sistem perdagangan barang dan jasa dengan media elektronik melalui mobile device; atau perdagangan yang menggabungkan basis elektronik dan mobile computing. Peralatan mobile yang biasanya dipergunakan adalah berupa smartphone, notebook, PDA, dan telepon genggam. Perancangan aplikasi penawaran produk berbasis $m$ commerce diharapkan dapat membantu masyarakat Kecamatan Bruno Purworejo dalam mendekati konsumen untuk menjual arang aktif. Limbah tempurung kelapa yang telah diolah menjadi arang aktif diharapkan akan berhasil dipasarkan melalui marketplace yang berbasis $m$-commerce pada harga pasar yang bernilai ekonomi tinggi.

Berbagai aplikasi $m$-commerce telah banyak dikembangkan dewasa ini sehingga bisnis online semakin marak perkembangannya. Marketplace yang berbasis $m$-commerce telah banyak dikenal sebagai contoh adalah Shopee, Lazada, dan Tokopedia; dan masih banyak lagi marketplace yang sering diakses oleh publik. Dalam sebuah marketplace, penjual dan pembeli akan melakukan kegiatan jual beli secara daring. Pada sebuah marketplace dapat dijumpai berbagai macam barang dan jasa yang ditawarkan oleh penjual. Barang dagangan ditawarkan dengan menampilkan foto-foto produknya sehingga dapat menarik minat konsumen yang disertai dengan informasi tentang varian, ukuran, harga, volume, serta informasi lain yang kira-kira dibutuhkan pembeli.

Apabila masyarakat Kecamatan Bruno telah mengerti bagaimana bertransaksi di marketplace yang berbasis $m$-commerce untuk memasarkan produk arang aktif, diharapkan arang aktif, dapat dipasarkan dengan mudah dan memiliki omzet yang tinggi. Hasil penjulan ini seterusnya dapat menjadi alternatif sumber penghasilan dan perekonomian setiap keluarga dan masyarakat Kecamatan Bruno pada umumnya.

Berdasarkan pemaparan latar belakang di atas, maka dapat dirumuskan beberapa permasalahan yg ditemukan di masyarakat Kecamatan Bruno, yaitu:

a. Belum dimilikinya pengetahuan mengolah limbah tempurung kelapa menjadi arang karbon aktif.

b. Belum dimilikinya alat produksi untuk mengolah limbah tempurung menjadi karbon aktif.

c. Belum dimilikinya pengetahuan pemasaran khususnya pemasaran menggunakan marketplace yang berbasis $m$-commerce dan mapping calon pembeli. 
Program Pengabdian kepada Masyarakat ini bertujuan untuk dapat memberi solusi atas problem-problem di atas sehingga dapat tercapai tujuan program yaitu menaikkan tingkat perekonomian masyarakat serta membuka lapangan pekerjaan bagi masyarakat Bruno. Adapun tujuan program ini dapat dirumuskan sebagai berikut:

a. Tutorial dan penataran pengolahan limbah tempurung kelapa menjadi karbon aktif kepada masyarakat

b. Melaksanakan pelatihan dan praktik memproduksi karbon aktif

c. Menyerahkan bantuan pengadaan peralatan produksi karbon aktif dari limbah tempurung kelapa

d. Memberikan pengetahuan teoretis tentang bisnis menjual dan promosi produk secara digital

e. Melaksanakan pelatihan pemasaran dengan menggunakan marketplace berbasis mobile phone dan media sosial sehingga dapat menjangkau pasar yang luas

f. Membentuk unit produksi karbon aktif dan pemasaran produk akhir.

\section{Metode Pelaksanaan}

Metode yang digunakan untuk melaksanakan program pengabdian kepada masyarakat ini adalah pembekalan teoretis yang diikuti dengan pelatihan serta praktik dan diserahkan juga bantuan mesin produksi agar supaya program dapat terlaksana. Kegiatan ini dilaksanakan di Kecamatan Bruno, Purworejo pada bulan April sampai dengan Mei 2019. Adapun langkahlangkah operasional pelaksanaan kegiatan Pengabdian Masyarakat ini disajikan pada Tabel 1 di halaman berikutnya.

\section{Pembahasan}

Kecamatan Bruno, Purworejo memiliki potensi buah kelapa yang berlimpah. Limbah tempurung buah kelapa selama ini oleh masayarakat digunakan hanya sebagai substitusi kayu bakar untuk keperluan rumah tangga sehingga sama sekali tidak memiliki nilai ekonomis. Karbon atau arang aktif sebagai material berpori/adsorben dapat dihasilkan melalui pemrosesan lebih lanjut limbah tempurung kelapa. Material adsorben adalah materi penyerap dari zat pengotor yang terdapat dalam air maupun udara. Karbon aktif dibutuhkan oleh industri penghasil limbah cair sebagai bahan pengolah atau penetralisisr limbah cair sehingga merupakan produk yang bernilai ekonomis. Penjualan karbon aktif dengan harga pasar yang baik dapat berperan meningkatkan pendapatan keluarga dan masyarakat. Lebih jauh lagi apabila terbentuk sebuah unit produksi tempurung kelapa di setiap desa maka dapat menciptakan lapangan kerja baru. 
Tabel 1. Langkah-langkah Operasional dan Urutan Kegiatan/Aktivitas

\begin{tabular}{|c|c|c|}
\hline No & Aktivitas & Frekuensi \\
\hline 1 & Melaksanakan pertemuan dengan pemerintah desa dan tokoh masyarakat (awal) & 1 kali: 2 jam \\
\hline 2 & $\begin{array}{l}\text { Menyusun business plan guna mengkoordinasikan dan merencanakan jalannya } \\
\text { usaha memproduksi dan menjual arang aktif dan menyamakan tujuan usaha }\end{array}$ & 8 jam \\
\hline 3 & $\begin{array}{l}\text { Pengenalan teknologi yang akan digunakan dalam melakukan produksi, dilakukan } \\
\text { dengan melaksanakan pertemuan dengan masyarakat }\end{array}$ & 1 kali: 2.5 jam \\
\hline 4 & Penyediaan peralatan produksi & 1 kali \\
\hline 5 & Pelatihan pengolahan limbah tempurung menjadi Bahan Penyerap (Arang Aktif) & 2 kali: 4 jam \\
\hline 6 & Praktik pengolahan tempurung hingga menjadi Bahan Penyerap (Arang Aktif) & 3 kali: 6 jam \\
\hline 7 & Sosialisasi pengenalan pasar, strategi pemasaran & 2 kali: 4 jam \\
\hline 8 & $\begin{array}{l}\text { Pelatihan pembuatan akun di marketplace dan penggunaan media sosial sebagai } \\
\text { alat pemasaran produk }\end{array}$ & 3 kali: 6 jam \\
\hline 9 & Praktik pembuatan media pemasaran produk secara OL & 3 kali: 6 jam \\
\hline 10 & Pelatihan mendesain leaflet sebagai alat pemasaran produk & 1 kali: 2jam \\
\hline 11 & $\begin{array}{l}\text { Melaksanakan penutupan rangkaian kegiatan melalui pertemuan dengan } \\
\text { pemerintah desa, tokoh masyarakat serta masyarakat yang terlibat menangani } \\
\text { proyek (akhir) }\end{array}$ & 1 kali: 2 jam \\
\hline
\end{tabular}

Gambar 1 A, B, C berikut ini memperlihatkan beberapa aktivitas dalam pelaksanaan program pengabdian seperti yang disebutkan di dalam Tabel 1. Peralatan atau mesin-mesin produksi yang nampak pada Gambar B dan $C$ disediakan oleh program ini disumbangkan kepada masyarakat. Peralatan lain yang juga disediakan diantaranya berupa alat penghalus serta penyaring.

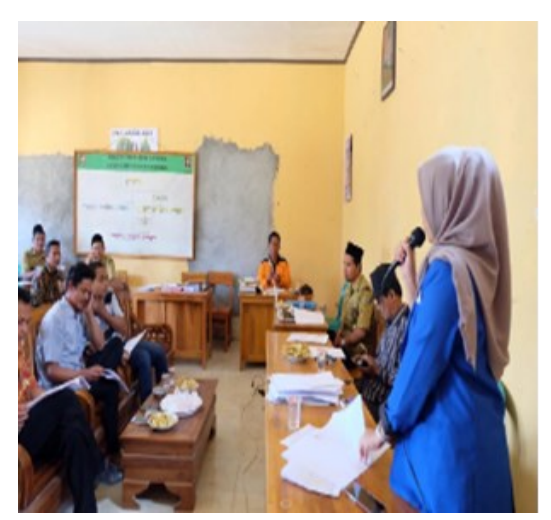

(A)

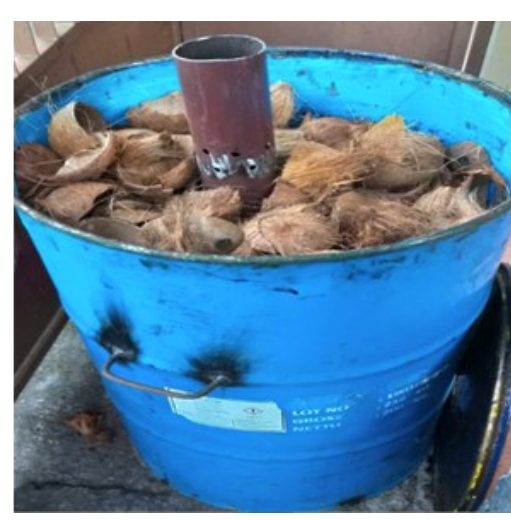

(B)

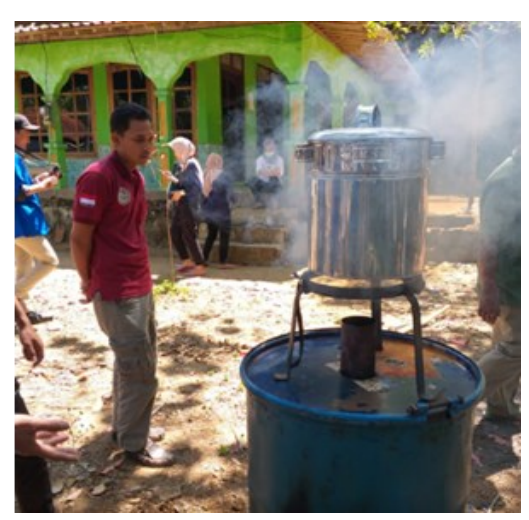

(C)

Gambar 1. A. Pengenalan program pembuatan karbon aktif dan $m$-commerce kepada masyarakat Kecamatan Bruno

B. Persiapan pemrosesan tempurung kelapa dalam reaktor

C. Pembakaran tempurung kelapa diproses menjadi arang aktif

\section{Kebutuhan Pasar}

Permintaan pasar akan karbon aktif di Indonesia sangat besar terbukti dari tinggi dan terus meningkatnya nilai impor karbon aktif (KA). Data dari Badan Pusat Statistik menunjukan bahwa kebutuhan impor karbon aktif terus 
mengalami peningkatan. Kenaikan impor KA mengindikasikan tingginya kebutuhan dan permintaan produk KA di dalam negeri akan tetapi tidak bisa dipenuhi dari produksi dalam negeri di Indonesia. Data volume impor karbon aktif yang meningkat dari tahun 2011 sampai dengan tahun 2018 disajikan pada Tabel 2 berikut ini (Badan Pusat Statistik, 2020).

Tabel 2. Data Impor Karbon Aktif

\begin{tabular}{cc}
\hline Tahun & Kebutuhan Karbon Aktif (Ton) \\
\hline 2011 & $5.444,834$ \\
2012 & $6.650,384$ \\
2014 & $8.842,249$ \\
2015 & $9.366,417$ \\
2016 & $9.176,328$ \\
2018 & $11.860,851$ \\
\hline Sumber: Badan Pusat Statistik (2019)
\end{tabular}

Produksi KA tidak hanya dibutuhkan untuk keperluan industri dalam negeri tetapi juga untuk diekspor untuk memenuhi permintaan beberapa negara industri. Pasar dalam negeri menyerap $70 \%$ produksi hasil pengolahan karbon aktif di Indonesia. Di Indonesia karbon aktif diantaranya dipergunakan dalam industri farmasi, pabrik bahan kimia, pabrik makanan, MSG, air mineral, dan perminyakan (Meisrilestari, 2013). Karbon aktif diperlukan sebagai bahan penyerap untuk mengatasi polusi lingkungan sebagai akibat dari limbah cair atau gas hasil sisa pembuangan pabrikpabrik. Gambar 2 menyajikan beberapa manfaat karbon aktif untuk berbagai keperluan baik rumah tangga maupun diolah menjadi produk oleh industri farmasi sebagai obat pencahar dan pasta gigi.
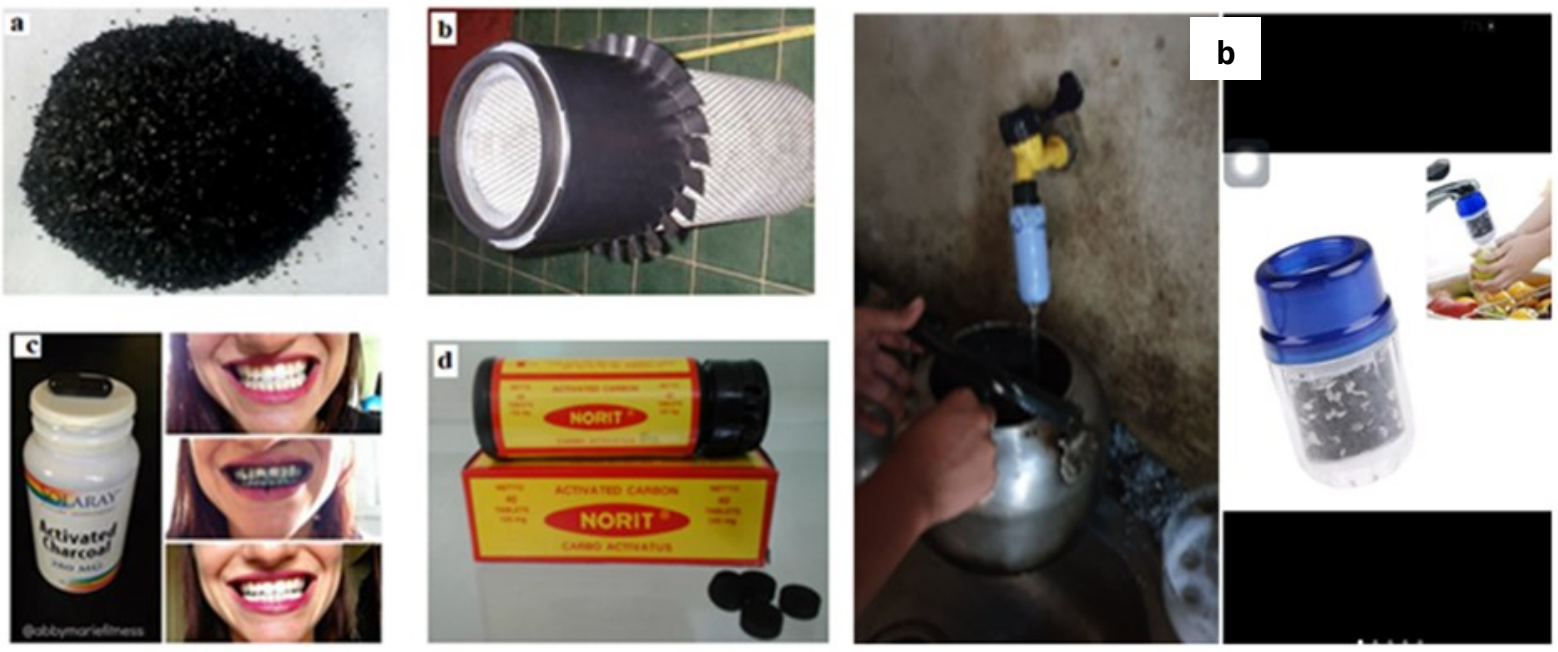

Gambar 2. A. Karbon aktif.

Penggunaan Karbon Aktif sebagai:

B. Filter air, C. Pasta gigi; D. Norit obat sakit perut

\section{Pemasaran Produk}

Seperti halnya produk lain, memasarkan produk arang tempurung harus diawali dengan tahap mengenalkan produk ini kepada masyarakat luas. 
Diharapkan setelah produk arang aktif dari Kecamatan Bruno ini dikenal maka akan datang banyak pesanan penjualan, baik konsumen perorangan, rumah tangga, maupun pesanan dan permintaan penjualan dari industri.

Mempertimbangkan kemajuan teknologi informasi dan juga lokasi Kecamatan Bruno, kondisi masyarakat dan lingkungannya, maka metode pemasaran secara online menjadi pilihan yang cocok. Jalur pemasaran online dipilih karena pada tahap awal memasarkan produk, penjual tidak harus memiliki kantor dan toko secara fisik; dan yang lebih penting lagi karena penjualan secara online mampu menjangkau wilayah pemasaran produk tanpa batasan wilayah dan waktu.

Saat ini bertransaksi secara online menggunakan berbagai macam marketplace telah biasa dilakukan orang. Masyarakat dari semua kalangan, di mana pun berada sudah mengenal model pemasaran ini. Tidak terkecuali masyarakat di Kecamatan Bruno. Meskipun demikian, dalam bertransaksi mereka berperan sebagai konsumen dan bukan sebagai penjual. Ketika harus berdagang dan menjual karbon aktif, maka posisi masyarakat Bruno adalah sebagai penjual. Sebagian besar masyarakat Bruno belum memiliki pengalaman ketika harus menjadi penjual produk. Mereka belum memahami seluk beluk bagaimana memasarkan dan menjual produk di markeplace. Oleh karena itu, pelatihan sangatlah diperlukan. Dengan pelatihan maka akan diketahui apa saja persiapan yang harus dilakukan ketika harus menjual produk dan memaksimalkan pemasaran di marketplace.

M-commerce menjadi sebuah pilihan model pemasaran yang tepat sebab dapat menyelesaikan keterbatasan yang dihadapi masyarakat Kecamatan Bruno. Mereka membutuhkan media untuk memasarkan produk agar lebih cepat dikenal luas ke seantero tempat dan wilayah. Metode pemasaran online dengan m-commerce ini amat memudahkan baik dari sisi penjual maupun pembeli. Sementara dari sisi peralatan yaitu handphone, smartphone dan jaringan internet tidak lagi menjadi kendala bagi penduduk Bruno; bahkan beberapa kalangan masyarakat sudah familiar. Program pelatihan perancangan m-commerce dapat membantu masyarakat Kecamatan Bruno untuk mengatasi kesulitan memasarkan produk karbon aktif sebagai sumber penghasilan keluarga dan meningkatkan perekonomian masyarakat desa.

\section{Aktivitas Pengabdian Kepada Masyarakat}

Berikut ini dijabarkan empat aktivitas utama program pengabdian kepada masyarakat yang dilaksanakan di Kecamatan Bruno Purworejo sebagai penjelasan Tabel 1 yang dipaparkan pada halaman sebelumnya,

Aktivitas Pertama: pengenalan teknologi dan penyediaan peralatan yang akan digunakan untuk memproduksi arang tempurung adalah:

a. Pembuatan reaktor dengan penutup rapat yang memanfaatkan (terbuat dari) drum bekas berfungsi sebagai oven limbah tempurung

b. Menyediakan kompor gas sebagai alat pemanas reaktor untuk mengoven limbah tempurung sehingga menjadi arang tempurung kelapa. Arang akan diproses lebih lanjut 
c. Menyediakan alat penghalus hasil arang tempurung

d. Menyediakan alat pengayak

Aktivitas kedua: Praktik pengolahan tempurung hingga menjadi bahan penyerap (menjadi arang aktif) urut-urutannya adalah sebagai berikut:

a. Reaktor sebagai oven disiapkan untuk pembuatan karbon aktif.

b. Tempurung kelapa dipotong kecil-kecil dan dimasukkan ke dalam reaktor dan diisi air sebagai aktivator.

c. Reaktor dipanaskan dengan kompor pada suhu tinggi sampai dengan $500^{\circ} \mathrm{C}$.

d. Setelah kering dan terbentuk karbon aktif, maka arang tempurung akan dihaluskan dengan alat penghalus dan diayak untuk memisahkan ukuran karbon aktif

e. Arang yang sudah diayak akan dikemas kemudian akan disimpan dan siap untuk dipasarkan (Nustini \& Allwar, 2019).

Aktivitas ketiga: pembekalan pengetahuan tentang teknik pemasaran menggunakan $m$-commerce melalui sebuah marketplace yang bonafide dan dapat dipercaya.

Setelah tempurung kelapa berhasil diproduksi menjadi arang aktif, maka langkah selanjutnya adalah memberi Pelatihan dan Praktik pembuatan media pemasaran produk secara online. Dalam materi pembelajaran dijelaskan bahwa sebelum memulai menjual arang aktif menggunakan sebuah aplikasi marketplace, maka perlu diperhatikan beberapa hal berikut ini:

a. Produk arang aktif harus terjaga kualitasnya. Tujuannya adalah agar produk yang ditawarkan dapat bersaing di pasaran dengan produk yang sama.

b. Menyiapkan deskripsi produk dengan saksama, utamanya penjelasan yang dapat menyampaikan kelebihan dan kualitas produk dengan kalimat yang mudah dimengerti. Penjelasan detail produk disesuaikan dengan ekspektasi konsumen.

c. Dibuat/disiapkan gambar/foto produk dengan jelas sehingga foto produk dapat mendeskripsikan dirinya. Foto harus dibuat semenarik mungkin dan digunakan foto asli. Konsumen lebih percaya kepada foto asli dari produk.

d. Mencantumkan berat, ukuran, harga barang. Harga barang harus bersaing dengan produk sejenis dan kualitas terjaga dan baik.

e. Membuka rekening tabungan di bank, disarankan memilih bank pemerintah. Nomor rekening pribadi ini akan dicantumkan ketika menawarkan produk.

f. Mengunduh aplikasi Shopee dan melakukan pendaftaran akun. Uruturutan cara melakukan pendaftaran dibantu melalui tutorial hands-on. Informasi yang harus diinput ketika membuat akun harus disiapkan, yaitu: profil diri, alamat pribadi, nomor handphone, alamat e-mail, social media lain yang dimiliki. Setelah semua informasi tersebut diinput, maka seseorang telah memiliki akun di Shopee. Shopee dipilih sebab saat ini Shopee adalah marketplace yang berada pada rangking pertama jumlah transaksinya, artinya paling banyak diakses oleh konsumen dan calon konsumen. 
Aktivitas keempat: Pembimbingan dan membantu kader pemuda Kecamatan Bruno, Purworejo melakukan pembuatan akun di marketplace Shopee secara hands-on. Peserta pelatihan diminta untuk membawa smartphone yang mereka miliki dan bersama-sama dengan dibantu beberapa tutor melakukan pembukaan "Toko" di Shopee. Peserta dibimbing untuk mengikuti petunjuk yang diberikan oleh Shopee step by step. Setelah pembuatan akun diverifikasi oleh Shopee, produk arang aktif dari Bruno sekarang sudah terdaftar di Shopee. Dengan memiliki aplikasi marketplace secara langsung, kita dapat lebih mudah menjalankan usaha di mana saja dan kapan saja. Salah satu Toko milik peserta pelatihan diberi nama "houseofwatuduwur" seperti nampak pada Gambar 3B2.

Saat ini pembuatan akun hanya dilakukan pada satu marketplace yaitu Shopee. Dengan pembukaan akun ini produk arang aktif dari desa-desa di Kecamatan Bruno mulai dikenal banyak kalangan yang memerlukan dan memperoleh pesanan penjualan. Setelah tutorial dengan dipandu, diharapkan peserta memahami dan dapat melakukan pembukaan akun sendiri di marketplace yang lainnya, misalnya Tokopedia, Lazada atau yang lainnya.

Pada Gambar 3A ditampilkan foto pengemasan produk arang aktif dengan merk "Arang dan Karbon Aktif WATUDUWUR - Bruno - Purworejo". Dapat diperhatikan pada Gambar 3B1 bahwa produk arang aktif dikemas dalam pax seberat 100 gram (1 ons) dengan harga Rp2.000 per pax. Selanjutnya, Gambar 3B2 memperlihatkan salah satu toko yang telah berhasil dibuat oleh peserta pelatihan, dengan nama "houseofwatuduwur". Nampak pada Gambar 3B2 "houseofwatuduwur" tidak hanya menjual arang aktif tetapi juga menjual produk bantal yang diisi dengan sabut kelapa yang telah diproses sebagai pengganti (alternatif) dari kapas dan dacron.

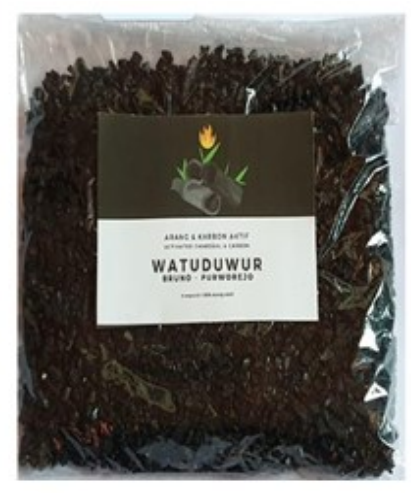

(A)

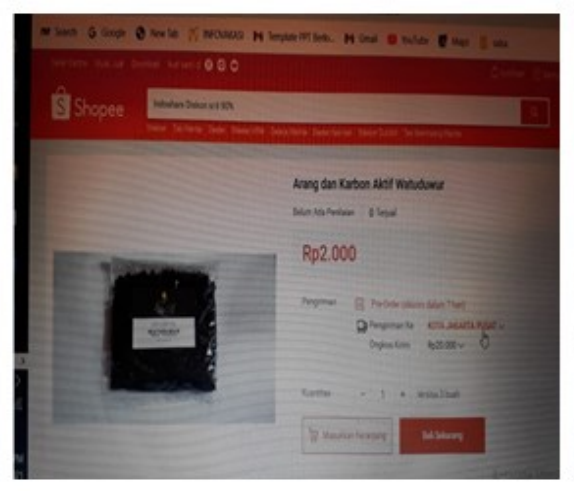

(B1)

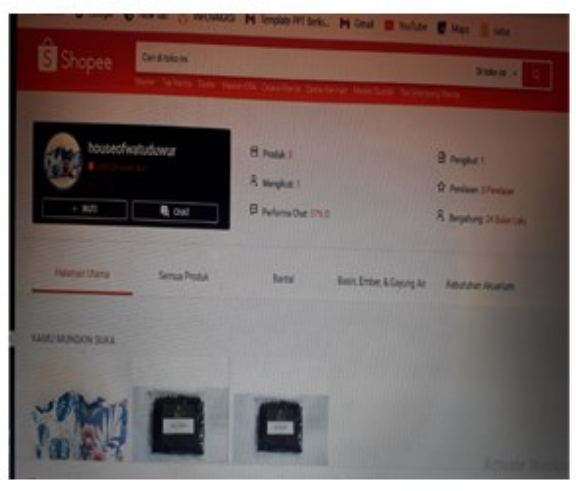

(B2)

Gambar 3. A. Produk Arang Aktif dalam Kemasan Siap Dijual

B1 dan B2. Tampilan Pemasaran dan Toko di Shopee (Sumber: Shopee, 2021)

\section{Perhitungan Hasil Penjualan dan Keuntungan}

Dari pemrosesan tempurung kelapa menjadi arang aktif ternyata juga dihasilkan produk sampingan berupa arang pembakar. Dihasilkannya produk sampingan disebabkan karena tidak semua output arang hasil 
pembakaran/pemrosesan tempurung kelapa dapat dijadikan arang aktif. Arang tempurung yang tidak memenuhi spesifikasi untuk diproses lebih lanjut menjadi arang aktif akan berfungsi menjadi arang pembakar. Produk arang pembakar juga laku dijual, jadi produk sampingan ini juga memiliki nilai ekonomis.

Penjualan dari dua macam produk yaitu produk utama arang aktif dan produk sampingan arang pembakar dapat menghasilkan pendapatan bagi masyarakat. Tabel 3 memperlihatkan perhitungan bahwa dari setiap pemrosesan $100 \mathrm{~kg}$ limbah tempurung kelapa dapat dihasilkan $12 \mathrm{~kg}$ produk utama dan $50 \mathrm{~kg}$ produk sampingan dengan kenaikan harga yang berlipat ganda dari bahan bakunya. Kenaikan harga sebagai produk arang aktif adalah sebesar 27,1 kali lipat, sedangkan harga arang pembakar naik 6,04 kali lipat dari harga tempurung.

Tabel 3. Hasil Pemrosesan Tempurung: Output Utama dan Output Sampingan

\begin{tabular}{lccc}
\hline Keterangan & $\begin{array}{c}\text { Bahan Baku } \\
\text { Tempurung } \\
\text { Kelapa (100\%) }\end{array}$ & $\begin{array}{c}\text { Output Utama } \\
\text { Arang Aktif (\%) }\end{array}$ & $\begin{array}{c}\text { Ouput Sampingan } \\
\text { Arang Pembakar (\%) }\end{array}$ \\
\hline Volume & $100 \mathrm{~kg}$ & $12 \%$ & $50 \%$ \\
\hline Harga & $\mathrm{Rp} 700 / \mathrm{kg}$ & $\mathrm{Rp} 19.000 / \mathrm{kg}$ & $\mathrm{Rp} 4.500 / \mathrm{kg}$ \\
\hline Kenaikan Harga/kg & $100 \%$ & $2.710 \%$ & $604 \%$ \\
\hline
\end{tabular}

Selanjutnya, perhitungan perkiraan jumlah pendapatan, keuntungan dan kenaikan (incremental) dari hasil penjualan arang aktif dan arang bakar ditampilkan pada Tabel 4.

Tabel 4. Perhitungan Pendapatan, Keuntungan dan Incremental Hasil Penjualan Arang Aktif dan Arang Pembakar

\begin{tabular}{|c|c|c|c|}
\hline Keterangan & Volume & Harga/Unit & Total \\
\hline Harga Bahan Baku Tempurung & $100 \mathrm{~kg}$ & Rp700 & Rp70.000 \\
\hline Harga Kemasan Plastik & $1 \mathrm{~kg}$ & Rp3.500 & Rp3.500 \\
\hline Biaya Operasional \& Pemasaran & $\begin{array}{r}10 \% \text { Harga } \\
\text { jual } 12 \mathrm{~kg}\end{array}$ & Rp1.900 & Rp22.800 \\
\hline Total biaya $(\mathrm{A})$ & & & Rp96.300 \\
\hline Harga Jual Arang Aktif (B) & $12 \mathrm{~kg}$ & Rp19.000 & Rp228.000 \\
\hline Harga Jual Arang Bakar (C) & $50 \mathrm{~kg}$ & Rp4.500 & Rp225.000 \\
\hline Perkiraan Keuntungan $(B+C)-A$ & & & Rp356.700 \\
\hline $\begin{array}{l}\text { Incremental Pendapatan Penjualan } \\
\text { Tempurung menjadi Arang Aktif } \\
\text { dan Arang Pembakar }\end{array}$ & $\begin{array}{r}\text { Rp356.700 / } \\
\text { Rp70.000 }\end{array}$ & $\begin{array}{c}=5,1 \mathrm{kali} \\
\text { atau } 501 \%\end{array}$ & \\
\hline
\end{tabular}

Tabel 4 memperlihatkan perhitungan untuk setiap $100 \mathrm{~kg}$ pemrosesan limbah tempurung, diperlukan biaya pengadaan tempurung, biaya pengemasan dan biaya opersional lainnya sejumlah (A) Rp96.300. Apabila semua produk jadi terjual maka diperkirakan akan diperoleh hasil sebesar (B) Rp228.000 dari penjualan arang aktif, dan (C) Rp225.000 dari hasil penjualan arang bakar, sehingga menghasilkan keuntungan sebesar 
Rp356.700. Jumlah keuntungan tersebut setara dengan 5,1 kali lebih tinggi atau $501 \%$ apabila dibandingkan dengan pendapatan dari penjualan limbah tempurung kelapa tanpa diproses lebih lanjut dimana harga per kg hanya Rp700.

\section{Kesimpulan}

Pengabdian masyarakat ini bertujuan agar masyarakat di Kecamatan Bruno, Purworejo dapat meningkatkan pendapatannya melalui pemanfaatan limbah tempurung kelapa yang banyak dihasilkan di desa-desa di Kecamatan Bruno, Purworejo.

Beberapa kegiatan telah terlaksana yaitu pelatihan pembuatan arang aktif sebagai produk utama pembakaran limbah tempurung kelapa. Di samping memberikan pelatihan, oleh karena peralatan belum dimiliki dan belum tersedianya modal untuk pengadaannya maka program ini menyerahkan bantuan peralatan pemrosesnya. Mesin dan peralatan pemrosesan yang diserahterimakan di antaranya berupa reaktor, dandang, mesin penggerus dan peralatan untuk mengayak (proses penyaringan).

Aktivitas seterusnya adalah tutorial proses pengemasan (packaging) produk termasuk mendesain merek produk dan pembuatan foto produk dan deskripsinya. Aktivitas terakhir adalah tutorial dan hands-on pembuatan akun di marketplace Shopee dan seting pembukaan "Toko". Aktivitas terakhir ini merupakan Langkah menuju ke realisasi tujuan akhir dari pengabdian masyarakat ini, yaitu penjualan arang aktif sehingga menghasilkan pendapatan bagi masyarakat Kecamatan Bruno Purworejo.

Apabila bermaksud meneruskan program ini, program-program pengabdian masyarakat selanjutnya, dapat melakukan pemantauan keberlanjutan produksi arang aktif dan maintenance terhadap pemasarannya melalui marketplace. Pemantauan dan keberlanjutan pembimbingan sangat diperlukan mengingat kesuksesan pemasaran produk apapun perlu kesabaran, focus, dan keseriusan.

Seterusnya perlu dikembangkan penjualan menggunakan website atau media-media sosial bukan hanya melalui marketplace. Oleh karena itu, diperlukan program pengajaran/tutorial membangun website untuk mengembangkan pemasaran arang aktif dan produk-produk tempurung lainnya. Limbah hasil pohon kelapa yang lain berupa sabut buah kelapa. Pengembangan dan inovasi produk dari sabut kelapa yang juga tersedia melimpah di desa-desa di Kecamatan Bruno merupakan sumber pendapatan berikutnya.

\section{Ucapan Terima Kasih}

Ucapan terima kasih disampaikan kepada Direktorat Penelitian dan Pengabdian Kepada Masyarakat (DPPM) Universitas Islam Indonesia yang telah mendanai program ini. 


\section{Referensi}

Badan Pusat Statistik. (2020). Pertumbuhan Ekonomi Indonesia Triwulan IV2019. https://www.bps.go.id/2020

Meisrilestari, Y., Khomaini, R,. \& Wijayanti, H,. (2013). Pembuatan Arang Aktif Dari Cangkang Kelapa Sawit Dengan Aktivasi Secara Fisika, Kimia Dan Fisika-Kimia. Konversi. 2(1). 45-50. DOI: http://dx.doi.org/10.20527/k.v2i1.136

Nustini, Y. \& Allwar A. (2019). Pemanfaatan Limbah Tempurung Kelapa Menjadi Arang Tempurung Kelapa dan Granular Karbon Aktif Guna Meningkatkan Kesejahteraan Desa Watuduwur, Bruno, Kabupaten Purworejo. AJIE - Asian Journal of Innovation and Entrepreneurship. 4(3). 217- 226

Shopee. (2021) https://shopee.co.id/search?keyword=arang\%20dan\%20karbon\%20 aktif\%20watuduwur 